\title{
Insuring the Transatlantic Slave Trade ${ }^{1}$
}

\section{ROBIN PEARSON AND DAVID RICHARDSON}

The forced transportation of over $12.5 \mathrm{~m}$ Africans to the New World between the sixteenth and nineteenth centuries was 'one of history's greatest crimes against humanity'. ${ }^{2}$ It reached its peak in the late eighteenth century, by which time Britain had established itself as the leading slaver nation, carrying 40 per cent (1.6m) of all Africans transported between 1761 and the abolition of the British trade in $1807 .{ }^{3}$ The classic triangular pattern of the trade encompassed three legs: the outward voyage from a British or European port to the western coast of Africa where captives were purchased and loaded, the infamous 'middle passage' from Africa to the Americas, and the voyage homeward to Europe. Rising real prices for sugar and slaves, improvements in the productivity of plantation labor, together with high attrition rates among existing slave populations and newly arrived captives, led to a growing demand from the Americas, so that the average number of Africans transported rose from

\footnotetext{
* Earlier versions of this paper were presented at the Universities of Nottingham and Umeå. We are most grateful to the participants, as well as to the Editor of this JOURNAL and to two anonymous referees, for their insightful comments.

2 Davis, "Foreword", p. xvii.

3 The other major trading nations were Portugal/Brazil, who carried 32 per cent of captives transported between 1761 and 1807, and France (17 per cent). The most important of the minor participants were American and Dutch ships (six and three per cent respectively). Calculated from www.slavevoyages.org, accessed 4 November 2017.
} 
around 20,000 a year in the late seventeenth century to over 80,000 a year in the period 1781$1810 .^{4}$

A critical factor enabling the transatlantic slave trade to grow to such dimensions was the ability of the merchants to find ways to mitigate not only the usual risks of trans-oceanic commerce in a pre-industrial age, but also those risks peculiar to the trade itself. The latter included high crew and slave morbidity rates, highly variable loading rates and ocean crossing times and the difficulties of provisioning for these, the moral hazard of crew neglecting their cargoes or trading for themselves, losses caused through shipboard slave revolt or resistance, and a variety of transaction risks, including exchange value uncertainties, price volatility and planter credit default in the purchase of new slaves. Historians have noted how failure to manage such risks undermined the trading capacities of some companies involved in the slaving business. ${ }^{5}$

It is evident, nonetheless, that a wide range of measures was employed to try to mitigate or manage these risks. Some of these are discussed further below. Our primary focus in this paper, however, is on one important risk mitigation device largely neglected by historians, namely the insurance of ships and goods on all legs of the trade, and their human cargoes on the middle passage. ${ }^{6}$ The insurance of slaves at sea was already known in the

\footnotetext{
$4 \quad$ Eltis, Lewis and Richardson, "Slave Prices".

$5 \quad$ Carlos, "Bonding”.

6 There is no mention of insurance in, for instance, Klein, Atlantic Slave Trade; Curtin,
} Atlantic Slave Trade; Haggerty, "Risk and Risk Management", and only brief references in the principal studies of the French, Dutch and Portuguese/Brazilian trades. Stein, French Slave Trade; Postma, Dutch Slave Trade; Miller, Way of Death. The exception is Inikori, Africans, discussed below. 
fifteenth-century Mediterranean, where small numbers were occasionally included in policies covering maritime cargoes. ${ }^{7}$ From the late seventeenth century onward the expansion of transatlantic commerce raised it to an entirely new level. The annual average number of slaves carried by British ships in the first half of the eighteenth century rose by 68 per cent, a faster increase than that of shipping tonnage and probably Atlantic trade in general. ${ }^{8}$

Moreover, insurance was becoming increasingly available. By the 1720s London insurers included the slave trade among so-called "cross risks," that is ships or cargoes travelling between two or more foreign destinations outside the United Kingdom. In 1731 as much as 42 per cent of marine insurances sold by the London Assurance Corporation were "cross risks". For private underwriters the percentage was probably higher, especially when the two London insurance corporations withdrew from the cross-risks market during wartime. ${ }^{9}$ We do not know precisely what proportion of cross-risks insurance was accounted for by the slave trade, but given the relative rates of expansion noted above, it is probable that it became more important as a source of revenue for insurers (discussed further below). Of the 74 slaving

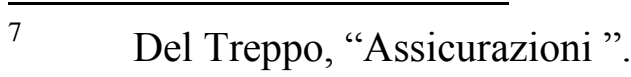

$8 \quad$ On average per annum 151,877 slaves embarked 1701-10, and 255,346 in 1751-60.

Calculated from www.slavevoyages.org (accessed 4.11.2017). English shipping tonnage was 323,000 in 1702 and 421,000 in 1751, a 30 per cent growth. Combined trade with Africa, the Americas and the West Indies (average annual imports, exports plus re-exports at official values) rose from $£ 2.2 \mathrm{~m}$ to $£ 3.4 \mathrm{~m}$ between $1710-19$ and $1751-8$, a 54 per cent growth albeit for a shorter period. Calculated from Mitchell, British Historical Statistics, pp.448, 534.

9 Calculated from John, "London Assurance", table 1. The cross-risks proportion of London Assurance business varied considerably. It was 17 per cent in 1769-70. See also Cockerell and Green, British Insurance, p. 12. 
voyages operated by the Liverpool trader William Davenport between 1757 and 1784 for which accounts survive, all were insured. All of the 55 slaving voyages of James Rogers of Bristol in1784-1793 for which we have accounts carried insurance. From his study of Davenport's accounts, Richardson concluded "there is little doubt...that mid-eighteenthcentury slave-traders regularly insured their ventures." 10

The insurance of transatlantic slave voyages, however, has seldom been examined as a business. Cultural and legal historians have debated the meaning of insured slaves as human lives or property. ${ }^{11}$ The only macroeconomic analysis was by Inikori, who argued that the growth of British marine insurance was largely dependent on insuring slaving and its related trades. ${ }^{12}$ Little attention has been paid to the practice of insuring slave ships, and to the impact of insurance on the trade. This article represents the first attempt to examine the process and implications of underwriting transatlantic slave voyages. What were the risks, how were they assessed and priced, and why were they underwritten? What was the cost burden of insurance to merchants? To what extent were slave voyages self-insured or underinsured? Our primary focus is on the role that insurance played in the British slave trade. Comparisons are also drawn where possible to the transatlantic slave trades of other nations, but because of the current paucity of published information, a comprehensive examination of the role of insurance in these trades will have to await future research. ${ }^{13}$

\footnotetext{
10 Richardson, "Profits", p.71.

11 Armstrong, "Slavery”; Rupprecht, "Excessive Memories”; Rupprecht, "Uncommon

Case"; Oldham, "Insurance Litigation”.

$12 \quad$ Inikori, Africans, pp. 338-61.

13 See note 6 above.
} 
Very few individual policies insuring British slaving voyages have survived. Consequently, any analysis is dependent on other sources, notably merchants' records of the insurance they purchased, or, more rarely, brokers' underwriting books. Our analysis is based on a new dataset comprising the latter two types of source. The first consists of details of 69 insurance policies issued to the Bristol merchant James Rogers for 55 slaving voyages between 1784 and 1793 and recorded in his papers in the Chancery Masters Exhibits of the British National Archives. The details include the policy's date and place of issue, name of ship and its captain, route insured, amount insured, categories of property insured (ship, goods etc), premium rate paid, cost of policy, valuation of 'negroes per head' (recorded in 13 policies only), amounts covered by individual subscribers (underwriters) to the insurance and their names ( 28 policies), and notes on the terms and restrictions of the cover ( 23 policies), such as 'liberty to join convoy' or 'free from the loss by trading in boats', the last referring to the practice in parts of western Africa of using yawls or other small craft to barter for and carry slaves to the principal vessel. We have cross checked and expanded the information on these 69 insurances by linking them to their respective voyages in Richardson's gazetteer of Bristol slaving voyages which gives the value and composition of outlays and the dates of departure and return to Bristol. ${ }^{14}$ Our second source comprises the six underwriting books of Abraham Clibborn, which provide details of 330 insurance policies issued on slave ships, mostly departing from Bristol, between 1769 and $1775 .{ }^{15}$ Clibborn listed policies by the name of the firm broking the insurance rather than by individual voyage or ship's name.

Nevertheless, it is possible to reorganise the entries and extract the following information: issue date of policy (month and year only), broker's name, ship's name, amount insured,

\footnotetext{
14 Richardson, Bristol.
}

15 The National Archives, UK (TNA), C107/1-15, Chancery Masters Exhibits, James Rogers Papers; C107/11, Underwriting Books of Abraham Clibborn. 
premium rate paid, categories of property insured (ship, goods etc), route insured, fate of voyage. Supplementary data on the voyages insured - date of departure, destinations, value and composition of outlay - have also been gleaned from Richardson's gazetteer. Because cargoes and hulls on some voyages were insured in more than one policy, the 399 policies across our two sources covered an estimated 220 voyages. We believe that this is the largest dataset ever compiled for slave trade insurance. ${ }^{16}$

There is no reason to suspect that the information in these sources is inaccurate in any systematic way. They were compiled for private consumption only, their usefulness to their owners lay in their accuracy and there were no major incentives to falsify the records. ${ }^{17}$

16 Inikori's appendix 7.2 contains insurance premiums for 60 voyages $1757-1806$. His table 7.2 of insurance rates 1701-1807 does not specify the number of observations. Inikori, Africans, pp. 350, 510-11. Our definition of a voyage is determined by the contemporary insurance. Thus England to Africa to America, if insured in one policy, is counted as one voyage. Where two or more insurances are recorded for the same ship and same route and are dated within six months of each other, we assume that the policies cover the same voyage. A small number of time policies (10) recorded in the Clibborn books, where no route is specified, are counted as insuring one voyage each.

17 Legislation passed in 1788 (28 Geo. III c.54) stipulated heavy fines for British ships exceeding the loading limit of slaves per ton, but this regulation is said by some to have been widely ignored. Inikori, Africans, pp.246-7, 284-5. In any case our study does not draw on the types of records - log books and surgeons' journals - that were subject to inspection under these rules. Nor was taxation an incentive to falsify in our period. A flat sixpence stamp duty on insurance policies was first introduced by 5 William \& Mary (1694) c.21. From 10 Anne (1711) c.26 only stamped policies were valid in the English law of equity, so policyholders 
Moreover, to supplement and expand the information on the policies, a detailed study has been carried out of the extensive correspondence concerning many of these voyages found in the Rogers' papers. ${ }^{18}$

As well as analysing the business of underwriting slave voyages, we have two other objectives. First, we explore the meaning of slave insurance from the perspective of those directly involved in the trade. Was it about insuring lives or goods? Second, we provide new estimates of the importance of the slave trade to UK marine insurance. Did the former drive the growth of the latter, as Inikori claimed? We begin by exploring these issues.

\section{SLAVES AS CARGO: INSURING LIVES OR GOODS?}

On 29 November 1781 the master of the Zong, a Liverpool slaver becalmed in the doldrums and running out of provisions, threw 132 living slaves overboard on the assumption that insurance would cover the loss. When the underwriters refused the claim the owners successfully sued. The underwriters applied for a retrial. At the Kings Bench in May 1783 Lord Mansfield and his fellow judges ruled in favour of the applicants, finding that there was no evidence that the loss had been occasioned by "perils of the sea" covered by the standard marine insurance policy. ${ }^{19}$ Two years later Mansfield adjudicated another case, where a had an incentive to pay the duty. The first proportionate tax on amounts insured - 2s.6d per $£ 100$ insured (0.125 per cent) - was levied in 1795 by 35 Geo. III c.63. According to contemporaries this was widely evaded, but it was introduced two years after the last policies in our dataset were issued. On marine insurance taxation, see Park, Law of Marine Insurances, p.28; Walford, Insurance Cyclopedia, vol.3, pp.552-3.

18 See note 15 above.

19 Gregson v Gilbert (1783) 3 Doug KB 232; 99 ER 629, discussed in Clark, "Slave's Appeal”; Oldham, "Insurance Litigation"; Walvin, Zong. The standard SG (ship, goods) 
Bristol ship had lost 55 slaves during a revolt off the coast of Africa. The dispute centred on which losses the underwriters were liable for under the slave insurrection clause in the policy. The court ruled that they were to compensate for slaves shot dead or who died from wounds incurred directly in the struggle, but that they were not liable for deaths by other means, such as drowning, jumping overboard or "abstinence" from despair at the failure of the uprising. ${ }^{20}$

In the aftermath of these and other cases, both legislators and the courts wrestled with the problem of how to define more precisely the "perils of the sea" as contained in the standard Lloyd's policy and restated in the Dolben Act of 1788, the first major British regulation of slave shipping. ${ }^{21}$ Legal ambiguities persisted. In 1794, breaking from standard policy conditions, parliament prohibited the recovery of slave losses due to jettison or as a result of quarrels with rulers on the African coast that derived from aggressive procurement by British crews. ${ }^{22}$ At the same time, however, the standard underwriters' exemption from

policy insured a hull and/or cargo against the "perils of the seas, men-of-war, fire, enemies, pirates, rovers, thieves, jettisons, letters of mart and countermart, surprisals, takings at sea, arrests, restraints, and detainment of all kings, princes and people". Perils of the sea included loss or damage by shipwreck, stranding, burning or sinking, and loss damage or loss deliberately caused by master or crew. Cockerell and Green, British Insurance, pp.3-4. $20 \quad$ Jones $v$ Schmoll (1785) 1 Term Rep 130n, discussed in Park, System, pp. 56-7; Oldham, "Insurance Litigation”, pp. 308-10.

2128 Geo III (1788) c. 54, art. 12 prohibited insurance of "any Cargo of Slaves, or any Part thereof", except against "the Perils of the Sea, Piracy, Insurrection, or Capture by the King's Enemies, Barratry of the Master and Crew, and Destruction by Fire." See also 30 Geo. III (1790) c.33; 32 Geo. III (1792) c.52; 33 Geo. III (1793) c.73. 34 Geo III (1794) c.80, art. 10; 39 Geo. III (1799) c.80. 
liability for losses through natural death, wastage, spoilage, was confirmed in Tatham $v$ Hodgson (1796), where the court included within the definition of "natural death" the starvation of slaves by insufficient provisions occasioned by delays in a voyage due to bad weather or poor seamanship. ${ }^{23}$ The insurance of slaves was finally made illegal in 1807 by the same act that abolished the British slave trade, although some underwriters continued to insure slavers sailing under foreign flags. ${ }^{24}$

The Zong trial and other legal cases and atrocity stories became milestones in the campaign for abolition. Abolitionists protested that the slave trade wrongly conflated goods and persons. The Zong's crew, they argued, should be tried for murder. Shipboard revolts demonstrated the human desire of African slaves for liberty, rendering them something more than insurable cargo. Scholars have taken up these ideas and argued, largely from legal and abolitionist texts, that the status of the insured slave occupied "a middle position in the progress from insurance on goods to insurance on persons, providing a way of thinking about the value of a life." ${ }^{25}$ When slaves used their agency through suicide, revolt or other resistance, "insurance law struggled to know how to respond..."26 Insurance cases, and the abolitionist commentaries that accompanied them, "dramatised the consequences of legal perversion in the name of profit", so that "even the most hardened slavers tacitly acknowledged the ...irreducible humanity of a so-called human cargo.,27

23 Tatham v Hodgson (1796) 6 Term Rep 656, 101 ER 756; Park, System, pp. 62, 495; Oldham, "Insurance Litigation".

$24 \quad 47$ Geo.III c.36 §5. See also 46 Geo III c.52 §6; 51 Geo III c.23 $§ 12$. Armstrong, "Slavery”, p. 170. Swaminathan, "Reporting Atrocities".

26 Webster, “Zong”, p. 296.

27 Rupprecht, "Uncommon Case”, p. 334; Rupprecht, "Limited Sort". 
While the horrors of the middle passage may indeed have advanced the case for abolition, the focus on the latter has given rise to several misconceptions about how the trade regarded slaves and their insurance. Among the extensive private accounts and correspondence of merchants, factors, ships' captains and surgeons that we have examined, there is not a hint that slaves were regarded by those involved in the business as anything other than a cargo of goods. In the papers of James Rogers covering 1784-93, the very decade in which the general recognition of the humanity of slaves is supposed to have occurred, the most frequent term in the trade for a slave cargo was "parcel". The real value of a "parcel" was determined by the ethnicity, size, height, age, gender, state of health and physical appearance of the slaves comprising the "parcel" at the time of sale, together with the arithmetic of external factors in the market concerned, primarily the supply of and demand for slaves, the state of the sugar crop, and the state of planters' credit at the time of a ship's arrival, minus the cost of purchase on the African coast and the cost of provisions on the middle passage. ${ }^{28}$ There were similarities with the common Dutch and French methods of quantifying slave cargoes as piezas de India (PI), by which an adult male aged 15 to 35 , and 'without major blemish...good in health, not blind, lame, or broken' was counted as one PI, while women and children were counted as various fractions of one. ${ }^{29}$

Underwriters and their clients uniformly classified slaves as perishable goods. In his 1781 digest of English insurance laws and practices John Weskett placed slaves alongside cattle as class II common hazards. ${ }^{30}$ The association of slave and livestock cargoes continued

\footnotetext{
28 Clark, "Slave's Appeal", also cites the slang term "logs" for British slave cargoes.

29 Postma, Dutch Slave Trade, 37-8, 228-9; Stein, French Slave Trade, 85.

30 Weskett, Digest, p. 105. The categories were "least hazardous", "common hazardous", "more hazardous" and "most hazardous".
} 
to be made by English courts long after abolition. ${ }^{31}$ It was also found in maritime codes and trading practices elsewhere in Europe. The principal compilation of Portuguese commercial law and practice "bluntly headed its chapter regarding insurance for cargoes at sea as 'marine insurance for slaves and beasts'. ${ }^{32}$ Article 44 of the French Code Noir declared slaves to be "moveable stock" (meubles) and therefore a legitimate object of marine insurance. ${ }^{33}$ The Dutch used the word kop (head) for individual slaves, the same term used for cattle. ${ }^{34}$

In most maritime codes, perishable goods, as well as goods of high value or strategic worth, had to be described and have their value specified in the policy as a means of reducing the opportunity for fraud. ${ }^{35}$ This stipulation was important because, as noted above, insurers commonly were not held liable for "natural deaths" or "natural wastage", "corruption" or "spoilage" (including sickness) of perishable goods. On the other hand, they were liable for damage and losses through "perils of the sea", including goods jettisoned to save a ship in trouble and losses incurred in putting down shipboard revolts that could justifiably be said to endanger ship and crew. Thus it was important for loss adjusters to be able to distinguish between these two types of indemnifiable and non-indemnifiable losses in the event of a claim.

$31 \quad$ Cf. Lawrence v Aberdein (1821), 106 ER 1133.

$32 \quad$ Miller, Way of Death, p. 394.

33 Émerigon, Traité, p. 208.

34 Postma, Dutch Slave Trade, 227. Dehumanizing terms were also applied by Dutch and French slavers to elderly, sickly, disabled or very young captives who remained unsold, namely "macrons" or manquerons" (Dutch), and "queues de cargaison" (French). Postma, Dutch Slave Trade, 229; Geggus, "French slave trade", 127. 35 Weskett, Digest, p.261. 
The "natural deaths" exemption clause had a long history. It was found in the policies of fifteenth-century Catalan merchants and in the French maritime ordinance of $1681 .^{36}$ French legal commentators agreed that when "animals or negroes" died a "natural death", or also where slaves committed suicide through despair, the insurer was not to be held liable. ${ }^{37}$ Similarly in the Brazilian trade slavers could not insure their cargoes against common mortality, hence the practice of killing the first slaves to show any signs of a disease feared to be contagious, to save the costs of mortality among the remainder. ${ }^{38}$

As we have seen, for those arguing for a post-Zong transition in attitudes towards slave cargoes, the question of insurance losses during shipboard revolts is central. Armstrong, for example, has claimed that slaves were distinguishable from other goods by the "general average sacrifice" clause routinely inserted into slave ship policies. ${ }^{39}$ This exempted insurers from liability from claims arising from shipboard insurrection if the losses amounted to less than ten per cent of the total value of the cargo, hull and outfit. The argument was that the application of general average to slaves lost in insurrection imbued them in the eyes of underwriters with human agency. General average, however, was merely an accounting device to facilitate the adjustment of losses on certain goods as an average on the value of the ship and all cargo. It was widely applied to other perishable goods, including cattle and

36 Del Treppo, “Assicurazioni ”, p.23; Weskett, Digest, pp.260-1. There were similar clauses in the maritime ordinances of Prussia, Hamburg, Sweden and Florence.

37 Valin, Nouveau, vol.2, p.55; Émerigon, Traité, pp. 208-9.

$38 \quad$ Miller, Way of Death, p.661.

39 Armstrong, "Slavery”, pp.170-5. See also Webster, “Zong”, p.291. 
horses, in the same measure and with the same level of excess of ten per cent. ${ }^{40}$ "Sacrifice" was understood by those involved in the trade not as a reference to the loss of lives, but to the sharing of the loss of a perishable cargo among the insured. Underwriters used the general average clause with its proportionate excess to hedge against small and pernicious claims on all types of cargo losses. Slaves were no exception. Underwriters and courts dealt with slave losses arising from shipboard revolt as the equivalent of damage and losses caused by livestock panicking during a tempest. ${ }^{41}$ Indeed in the Zong hearing Mansfield described the jettison of slaves as similar to the jettison or shooting of horses in a storm to save a ship. The problem for the Zong's owners was that the court found no evidence that the jettison was justified by any perils of the sea. Instead it was the master's negligence and seamanship that was deemed at fault, and thus there was sufficient doubt that insured losses were not recoverable to warrant a retrial. ${ }^{42}$

Those arguing that transatlantic slave cargoes were positioned somewhere between the insurance of lives and goods have also turned to French evidence suggesting that slaves were insured under ransom insurance policies as fictional "captives", as a means of

$40 \quad$ Weskett, Digest, p.263, citing the 1744 Ordinance of Amsterdam. The same clause was in the Rotterdam Ordinance of 1721. Magens, Essay, vol.2 p.95. Some general average clauses fixed the excess at five per cent.

$41 \quad$ Lawrence v Aberdein (1821), 106 ER 1133; Gabay v Lloyd (1825), 3 B\&C 793, 107 ER 927.

42 Oldham, “Insurance Litigation”, p.316; Clark, "Slave's Appeal”, pp.56-7; Lobban, "Slavery". 
circumventing the prohibition on insuring human lives. ${ }^{43}$ According to this fiction, insurance on slaves was to cover the risk of loss of the "ransom money" paid for them upon loading until the money was redeemed through their sale across the Atlantic. A related fiction was that slaves were captured "enemies" and therefore a peril of the sea and a legitimate object of maritime insurance. In his 1783 treatise Émerigon cited ancient sources that argued there was always a state of war between masters and slaves. Thus, when insurers underwrote a ship known to be in the slave trade, they knew it was taking on board "enemies" that would, if they could, cause the loss of the ship. ${ }^{44}$

This fiction of slaves as the object of ransom insurance appears, however, to be entirely derived from French legal and commercial commentaries. ${ }^{45}$ The ransom insurance described in other European maritime ordinances only referred to insurance against the loss of liberty of European crews, rather than their lives, if captured by Turks, Moors, Corsairs or Barbary Pirates. ${ }^{46}$ The French sources are in any case ambiguous. Émerigon also cites a Marseille admiralty case from 1776 that makes it clear that French courts regarded slaves as goods, without any reference to ransom or redemption (rachat) insurance. ${ }^{47}$ Exactly how

43 Armstrong, "Slavery", p.170. Insurance on lives was widely banned as a form of gambling that offended religious authorities, beginning with the Ordinances of Barcelona (1435) followed by similar prohibitions in the Netherlands, Italy, Sweden and France in the sixteenth and seventeenth centuries. Roover, "Marine Insurance"; Clark, Betting, pp. 13-16. $44 \quad$ “La révolte des Negres est donc une fortune de mer.” Émerigon, Traité, p.397.

45 Weskett, Digest, p.72; Valin, Nouveau, vol.2 p.55.

46 Cf. the Insurance Ordinances of Hamburg 1731 (article 10), Amsterdam 1744 (article 14) and Sweden 1750 (article 9): Magens, Essay, vol.2 pp. 225-7, 132-3, 259-310.

$47 \quad$ Émerigon, Traité, pp.199-205, 396. 
underwriters and their clients in France and elsewhere in Europe classified slave cargoes in practice, however, would require a close examination of individual merchant's records and underwriter's books, the sort of analysis that we have carried out for English slavers, but which for the slave trades of other European nations is beyond the scope of this article.

\section{THE SLAVE TRADE AND BRITISH MARINE INSURANCE}

Inikori was the first historian to attempt to measure the importance of the slave trade and the "Atlantic slave economy" to British marine insurance. It formed part of his broader argument about the importance of the trade to the British industrial revolution. ${ }^{48} \mathrm{He}$ defined three channels by which the "Atlantic slave economy" was linked to the insurance industry: premiums earned from insuring British slave voyages in the triangular trade; premiums earned from insuring the trade in slave-produced commodities between England and America, and on the re-export trade in American produce between Britain and Europe; and premiums from insuring in London the American trade of European powers. The latter, Inikori declared, was impossible to measure given the limited data. He estimated, however, that in the 1790s the first two channels - slave voyages and the British trade in slaveproduced goods - together accounted for 63 per cent of premiums earned by the British marine insurance industry (see table 1.1 column D). Thus, the slave trade and its related transatlantic commodity trades appear to have been hugely important to the growth of this key financial service.

48 Inikori, Africans, pp. 338-61. As recently as 1999 Clark remarked that "it is unclear how frequently English merchants actually insured slaves on the Middle Passage”, Clark, Betting, p.17. 
[Table 1 here]

The contribution of the slave trade to British economic development has been much debated. While some scholars are sceptical about its macroeconomic impact, arguing that the trade was small and profits precarious, others have pointed to the economic spin-offs and multiplier effects of capital accumulated from trade in slave-grown commodities circulating among British business networks during the late eighteenth and early nineteenth centuries. ${ }^{49}$ Slave traders were prominent investors, for instance, in the early London dock companies, but they were not necessarily a dominating presence in the City. According to Draper, planters' bills formed an important part of London finance, but, contrary to Inikori, they did not comprise the bulk of bills in circulation in London and provinces. In the same vein, Draper has also questioned Inikori's argument that slavery-related trades dominated marine insurance. He estimates, from data of the London Assurance Corporation for 1769-70, that 15 per cent of sums insured on marine insurance policies and one-third of premiums derived from African and West Indian trades at that time, levels well below those estimated by Inikori for the 1790s. ${ }^{50}$

As explained in our notes to table 1, Inikori's estimates were based on projecting total British marine insurance premiums backwards from John Julius Angerstein's figure of $£ 10.95 \mathrm{~m}$ in 1809 , given in his evidence to the Select Committee on Marine Insurance. ${ }^{51}$ Inikori took the ratio of premiums earned by London Assurance in 1809 to its average

49 Eltis and Engerman, "Importance"; Zahadieh, "Overseas Trade”, p.403; Pearson, "Collective"; Pearson and Richardson, "Networking"; Devine, Tobacco. 50 Draper, "City". 51 Report from the Select Committee on Marine Insurance, British Parliamentary Papers (hereafter BPP), 1810, IV, 314-15. Angerstein was a former chairman of Lloyd's. 
premiums for 1793-1807, and applied this ratio to Angerstein's figure to estimate average annual British marine insurance premiums for 1793-1807. He then employed the same method to estimate annual average total premiums for 1750-92 and 1720-50.

There are several problems with this back-projection method. First, Inikori obtained only approximate figures for London Assurance from a graph by A.H. John. ${ }^{52}$ Supple calculated more accurate average premiums for London Assurance from the annual data in the company records, and we have used these for our estimates. ${ }^{53}$ Second, Inikori ignored the marine business of the other insurance corporation, the Royal Exchange Assurance, which by the 1770s was over twice as large as that of London Assurance. The accuracy of Inikori's method partly depends upon the smaller insurer adequately representing the growth of British marine insurance. Our estimates, by contrast, utilise the combined premiums of both corporations, as given by Supple. ${ }^{54}$

Third, Angerstein derived his estimate of $£ 10.95$ m premiums in 1809 by applying a rate of 7.5 per cent - the "average rate of premiums for the last 22 years..." - to the amount insured by the corporations and by private underwriters in London, as calculated from returns of stamp duty in 1809 , plus an estimate for the amount insured in London on the British coasting trade. ${ }^{55}$ This, however, ignored British marine insurance written outside London.

\footnotetext{
$52 \quad$ John, "London Assurance", p.130.

$53 \quad$ Supple, Royal Exchange, p.61n2.
}

54 Supple gives the average premiums of London Assurance net of returns. We have increased these by 25 per cent to obtain gross premiums comparable with those of Royal Exchange Assurance. According to Supple, returns in the period 1796-1815 "averaged just over 25 per cent of gross premiums". Supple, Royal Exchange, p.62, table 3.1n. 
The Select Committee itself made an allowance for the latter and estimated the total sum insured to be $£ 162.5 \mathrm{~m}$, compared to Angerstein’s $£ 140.5 \mathrm{~m}$. Applying the rate of 7.5 per cent to $£ 162.5 \mathrm{~m}$ gives a total of $£ 12.19 \mathrm{~m}$ for marine insurance premiums in 1809 . Another member of Lloyd's, Joseph Marryat, thought that the Select Committee had underestimated the amount written outside London, and he calculated total insured on marine policies to be $£ 175.6 \mathrm{~m} .{ }^{56}$ Applying 7.5 per cent to this gives an upper bound of $£ 13.2 \mathrm{~m}$ premiums in 1809 (upper bound, because the average rate on Irish and coasting trades would have been lower than 7.5 per cent, which was more representative of the premium rate on foreign trade). Furthermore, when the percentage stamp tax on marine insurance was introduced in 1795 , Pitt estimated its yield based on a figure of $£ 104 \mathrm{~m}$ insured. ${ }^{57}$ At a rate of 7.5 per cent, this suggests $£ 7.8 \mathrm{~m}$ marine insurance premiums in that year. In short, taking all the above calculations into account, Inikori’s annual average of $£ 4 m$ premiums in $1793-1807$, backprojected from Angerstein's figure of 1809, is almost certainly too low, probably by at least 50 per cent. The result, we argue, is to overstate the importance of slaving and slave trade related insurance to British marine insurance in the 1790s and 1800s.

Our new estimates, shown in table 1, are based on the combined premiums of both corporations $1760-1810$ and the annual duty paid on marine insurance $1800-1809$. We have used these two components to derive decennial averages of British marine insurance premiums, 1760-1809, and the share in these of Inikori's estimated premiums earned on slave and West Indian trades. To do this, we calculate the combined stamp duty paid by the two corporations 1800-09 as a percentage of the total duty paid, and then multiply the combined premiums of the corporations by that percentage in order to obtain the total premiums earned

\footnotetext{
56 Marryat, Observations, p.289. Marryat became chairman of Lloyd's 1811-24.

$57 \quad$ Raynes, History, p.189.
} 
from British marine insurance in that decade. The same multiplier method - applying the market shares of the corporations to their actual premiums - is used to estimate total marine insurance premiums for the decades between 1760 and 1800. For this period, however, the corporation market shares are estimates based on several assumptions, explained in the notes to table 1 , about the growth of marine insurance before 1800 .

Our new estimates suggest that seven per cent of British marine insurance in the 1790s was accounted for by slaving voyages alone, while the slave and West India trades combined accounted for 41 per cent, well below Inikori's figure of 63 per cent for 17931807. Nevertheless, if not accounting for the great majority of the British marine insurance industry as Inikori claimed, the "Atlantic slave economy" still represented a sizeable portion by the end of the eighteenth century. Moreover, comparing our figure of 41 per cent with Draper's estimate of 33 per cent in 1769/70 suggests that the transatlantic slave trade and its related commodity trades may have increased somewhat in importance to British marine insurance during the final three decades of the eighteenth century, though this was probably not a linear trend as high wartime premiums were offset by reduced volumes of traffic (see Table 2). ${ }^{58}$

[Table 2 here]

$58 \quad$ Our estimates, however, may be regarded as upper bound. If the figure of $£ 7.8 \mathrm{~m}$ total marine insurance premiums in 1795, discussed above, is accurate, premiums earned from insuring the slave trade would have accounted for only five per cent $(0.41 / 7.8)$, and those from the slave and West India trades together 32 per cent $(2.52 / 7.8)$, of the total in the mid1790s. Thus, taking Draper's estimate as a base, slave trade insurance would have grown at about the same rate since 1770 as British marine insurance as a whole. 


\section{THE UNDERWRITING OF SLAVE VOYAGES}

\section{Risk distribution and under-insurance}

Owners of slave ships and their cargoes obtained insurance either indirectly through brokers or by directly contracting with an underwriter, who was often a fellow merchant. For voyages fitted out in London, the former method may have been important, though without a study of the way that London slave traders insured we remain unsure. It is likely that their access to insurance became easier during the late eighteenth century, as the activities of Lloyds brokers and underwriters became more differentiated and capacity there increased. By 1810 there were up to 1500 subscribers to Lloyds, of whom two-thirds were regular or occasional underwriters. $^{59}$

In the provincial ports the second method of insuring prevailed, with local slave merchants in Bristol and Liverpool commonly acting as underwriters for each other's voyages. Given the importance of local business networks, it is not surprising that the pattern of underwriting seems to have mirrored the well known ownership structure of the trade in these ports, whereby a few large and closely connected firms dominated the business, accompanied by a greater number of small firms fitting out a minority of ventures. ${ }^{60} \mathrm{We}$

$59 \quad$ There had been just 179 subscribers in 1775. Wright and Fayle, History, p. 218; Kingston, "Marine Insurance”, 389.

60 Of 359 Liverpool firms fitting out 878 'Guinea' ships between 1783 and 1793, just 10 accounted for 502 of these ships. In 1789-91 the four largest firms in London and Bristol employed respectively 61 per cent and 93 per cent of the entire tonnage in their port's slave trade. Inikori, "Market Structure", tables 1, 3. For similar accounts of ownership concentration in the British trade, see Anstey, Atlantic Slave Trade 1992, pp. 6-7; Richardson, "Profits", p. 68. On Liverpool networks, see Pearson and Richardson, "Business 
have analysed the distribution of insurance in 27 policies insuring $£ 83,150$ on 15 ships and cargoes undertaking six voyages from Bristol between 1784 and 1793. On 19 of these policies, James Rogers was the lead underwriter, insuring 29.3 per cent of the total. A further eight underwriters, including the closest partners of Rogers, wrote another 34 per cent of the total. Together these nine men wrote 64 per cent of the amount insured on these 27 policies. There was, however, a long tail of 54 others writing small sums - $£ 50, £ 100, £ 200$ - on either the ships or cargoes or both. By insuring each other's voyages, Bristol merchants saved five per cent on brokers' fees, while their business contacts and partnerships across the city and region doubtless mitigated the costs involved in finding insurance themselves. The data suggest the general capacity of the major provincial ports to provide sufficient cover for most of their own slaving voyages without significant resort to the London insurance market. Whether or not there was differential access to insurance cover among slave trading firms, leading to the kinds of market distortions that Dalton \& Leung have recently investigated, is impossible to say. As yet we know nothing about the dispersion, if any, of premium rates and insurance cover among firms of different sizes operating out of British ports. The greater productivity of the British trade compared to those of France and Portugal, however, suggests that such distortions in British insurance markets were relatively minor. ${ }^{61}$

Slaving voyages often required multiple policies, especially when goods were added to the cargo after the original policy had been issued, either before sailing or at different ports on the voyage. On the Rogers voyages sometimes these additional policies were written

Networking". Ownership structures in the French slave trade were also highly concentrated. Stein, French Slave Trade, 152-5; Viles, "Slaving Interest”, 535-6.

61 Dalton and Leung, "Dispersion and Distortions". We are indebted to an anonymous referee for drawing our attention to this reference. 
outside Bristol, mainly in Liverpool and London but also in Exeter. It was common, therefore, for policies to be written at different times before and during a voyage. On the African Queen, for instance, which departed Bristol in January 1792 and returned in May 1793, policies totalling £20,400 were issued on ship and goods in December 1791, February 1792 and May $1792 .^{62}$

As planters' payments for slaves in the Americas by the late eighteenth century were largely made in post-dated bills, merchants tended to insure their shares in total outlays to Africa and America only. Insurance on the ship on the return run, and on the small quantities of produce brought home from America, were often underwritten separately at a later date. Of the 330 policies listed in Abraham Clibborn's underwriting books for 1769-75, 227 combined the outward run to Africa and the middle passage in one insurance. Our data, however, also show that all segments of the triangular trade could be individually insured, as well as the direct trade to the West Indies, and direct voyages to and from Africa.

Establishing the extent to which the full values of ship, outfit and cargo were covered by insurance is more difficult. The business accounts that have survived do not always enable us to be sure that they include all the insurance issued for the voyage. As noted above, policies might be issued intermittently and by different underwriters in different places before and during a voyage. Far more so than fixed capital on land, the "replacement value" of a ship and cargo en route could change not only between different segments of a journey, but also within the same segment. Historians have carried out considerable research on the outlay costs (ship, outfit and goods) of slave voyages, and, as discussed below, we know that insurance amounted to, on average, about 10 per cent of these costs in the British trade during

62 TNA, C107/1-15, James Rogers Papers. I wonder if I should dig out more specific references, at least in terms of box numbers? 
the second half of the eighteenth century, but this does not tell us how often ships and their outfit and cargo were fully insured.

What can be said at present is that it is unlikely there was any systematic underinsurance in the maritime industry, especially in the slave trade where owners were often among the underwriters of their own ships and cargoes. British insurance companies did systematically limit insurance on property on land against damage by fire to 75 per cent of its replacement value, as a device to compel the insured to carry one quarter of the liability. ${ }^{63}$ However, the widespread presence of self-insurance in slaving voyages must have greatly alleviated the moral hazard problem in this business, especially as many of the other underwriters were partners of the owners or belonged to their wider business network.

Owners of slaving voyages did not always seek full coverage. Writing to James Rogers from Tortola in 1788, William Grumly reported on the sloop Lion:

I think there is no occasion for making an insurance on the sloop's cargo. She is a fine vessel, sails fast and [it is] summer time. Will be ready for sea 22 May, sail within 7-10 days. I am sorry I could not get her away before but such short crops. Every person here is pushed to get a freight and some vessels that has been here four or five months has not on board 50 hogsheads sugar. ${ }^{64}$

In short, a light cargo and a fast ship sailing in the summer induced the captain to avoid insuring the return leg to England. The Select Committee on Marine Insurance estimated in 1809 that 49 per cent of all insurable property at sea (£158m out of $£ 320 \mathrm{~m})$ was not covered by insurance.

63 Pearson, Insuring, pp.309-12.

64 TNA, C107/8, James Rogers Papers, William Grumly to James Rogers, 21 May 1788. 


\section{Risk assessment and rates}

What did underwriters take into account when assessing the risk of insuring a slaving voyage? From 1764 the key information for London underwriters was listed in Lloyd's Register, which itself was probably compiled from the private registers of Lloyd's members. This fell into three categories: data about the owner, master and crew; the route (port and destination); and the ship (tonnage, hull, number of decks, guns, construction history, condition). ${ }^{65}$ It is clear from our dataset that the two principal factors determining Bristol rates were the route and the time of sailing, particularly whether in peace or war. Table 3 presents average premium rates - measured as $£$ premiums per $£ 100$ insured (£\%) - from three different but consistent sources: the rates given by Inikori and those we have calculated from Abraham Clibborn's underwriting books and the accounts of James Rogers. All three sources show that average rates varied between different segments of the triangular voyage. Between the 1770s and 1790s premium rates for the middle passage (column 2 in table $3 \mathrm{~A}$, row 2 in tables 3B and 3C) were higher than the other two segments, though not much higher than those charged for the return journey from the Americas (column 3 in table 3A, row 3 in tables 3B and 3C). During wartime, with the increased risk of enemy privateers, the home voyage eastward attracted the highest rates (column 3 in table $3 \mathrm{~A}$, row 3 in table $3 \mathrm{C}$ ).

[Table 3 here]

Perhaps surprisingly, however, these differences in rates did not reflect the "actuarial" risk of losses at sea. Table 4 shows that in the period after 1760 more British slave ships were lost on the first and third segments of the triangular route than in the middle passage, and also

$65 \quad$ Wright and Fayle, History, p.86. 
that this pattern holds true for the transatlantic slave trade more generally. Why then were rates higher on the middle passage? As noted above and discussed further below, underwriters did not cover the "natural mortality" of slaves on board ships. Only the loss of slaves who died during shipboard insurrections, subject to an excess of 10 per cent, or of slaves that were jettisoned to save a ship from storms or shipwreck or other 'perils of the sea' could be insured, and both were fairly exceptional events (see below). Thus, slave mortality in the middle passage cannot explain the differential in premium rates. If premium rates for the middle passage had been determined solely by the risk of the wreck or destruction of the ship - our best approximation of the "actuarially fair" rate given the absence of data on other major insurable 'perils of the sea' - then the policyholders in our Clibborn-Rogers dataset would have been charged for the middle passage between one quarter to one-third of the premium rates that they actually paid. ${ }^{66}$

66 In this calculation we have applied the ratios of British slave ships wrecked on the middle passage to those wrecked on the outward (2.14) and return (2.88) legs respectively to the actual average premium rates for the outward and return legs charged on the Clibborn and Rogers voyages (the latter excluding the wartime year of 1793) as show in table 3. For example, the average rate for the outward leg in the Clibborn policies is $£ 2.3$ (Table 3B row 1). This figure, divided by the ratio of shipwrecks on the middle passage to those on the outward leg (2.3/2.14), gives an actuarially fair premium rate for the middle passage of $£ 1.1$. Applying the ratio of middle passage shipwrecks to those on the return leg to the Clibborn premium rate (Table 3B row 3) for the return leg (4.3/2.88) gives an actuarially fair middle passage premium rate of $£ 1.5$. Clibborn policies thus would have paid between $£ 1.1$ and $£ 1.5$, or just 22 per cent to 31 per cent of the rate $£ 4.8$ that was actually charged (Table $3 \mathrm{~B}$, row 2 ). Using the same method, the actuarially fair middle passage rates for the Rogers voyages 
[Table 4 here]

This finding does not mean that underwriters were necessarily irrational when pricing insurance for a slaving voyage. They may have imposed a higher rate for ships on the middle passage because they regarded all cross-risks as inherently riskier than voyages to and from England, although we know of no evidence that this was the case. More probably, they may have factored in a notional premium for the uncertainty of a ship on the high seas being endangered by carrying live, rather than inanimate, cargoes. Livestock such as horses or cattle could stampede in a storm or carry contagious diseases in the same way that slaves might resist control or fatally infect the crew, imperilling the safety of the ship and its navigation. Although the incidence of such events was probably well known, underwriters would have found it difficult accurately to predict at the outset whether the security and hygiene measures on any given voyage were sufficient to mitigate these risks fully. Similarly, the navigation hazards of the middle passage were well understood - the need to pick up the north east trade winds, the difficulty of passing through the equatorial doldrums without being becalmed for an uncertain and dangerous length of time, mid-ocean storms blowing a ship off course, the risk of tropical storms near the West Indies, the huge variation in crossing times. ${ }^{67}$ Yet it would have been difficult to price these hazards for individual ships with any 1784-92 would have been between $£ 1.1$ and $£ 1.4$, or 28 to 34 per cent of the actual average rate of $£ 4$. Average premium rates, as elsewhere in this paper, are given as $£$ per $£ 100$ insured.

67 Ships leaving Senegambia could move directly into the northeast trade winds, but from the 1760s Bristol and Liverpool ships traded principally from Sierra Leone to the Bight of Biafra and beyond. Morgan, "Liverpool's Dominance", table 1.2. This part of the coast had prevailing westerlies and a strong eastward current. The route to the West Indies 
degree of certainty, notwithstanding good information about the captain's expertise and the seaworthiness of the vessel.

Another possible explanation for the relatively high premiums for the middle passage may be that ships on this leg were more exposed to capture. In wartime, shipping losses rose and rates on most categories of marine insurance doubled, although there were substantial discounts or rebates if ships joined armed convoys. ${ }^{68}$ Convoy protection, however, was not available for the middle passage, but only for direct routes between Britain and the West Indies and back, as enemy privateers mainly hunted ships sailing outward through the Bristol and English channels or returning from the Americas. Moreover, it was easier for direct traders to get convoys because their schedules were more predictable. By contrast, slave voyages were timed to arrive in Africa in the dry season, which varied by coastal trading location, and, once their cargoes were sold in the Americas, they aimed to clear out for home as soon as possible in order to refit for Africa, without necessarily waiting for a convoy. ${ }^{69}$

commonly involved sailing south to the Equator to pick up the southeast trades, then turning north in mid-ocean to cross the doldrums for a second time to catch the northeast trades. Curtin, Atlantic Slave Trade, pp. 278-9. For large deviations from mean crossing times, see Postma, Dutch Slave Trade, p. 162; Stein, French Slave Trade, p.97. For the argument that Lloyd's underwriters were well informed about Atlantic navigation risks, see Leonard, "Contingent", p.52; Kingston, "Marine Insurance". $68 \quad$ Wright and Fayle, History, p.158.

69 Eltis, Lewis, and Richardson, "Slave Prices"; Behrendt, "Merchants". On the more concentrated seasonal voyage patterns in the direct trade to the West Indies, see Davis Shipping Industry, pp.279-80. 
As table 5 shows, marine underwriters charged large price differentials in summer and winter for some, though not all, routes in other trades, but these played little role in slave trade insurance. Most slave voyages departed from England to avoid the rainy season in Africa, and left the Caribbean before the onset of the hurricane season in August. ${ }^{70}$ The repeated advice of West Indian factors to owners was to have slave cargoes arrive at market just prior to or at the start of the sugar harvest, when demand for newly imported slaves was highest and when planters were most likely to agree to shorter terms on their bills, subject, of course, to the state of that year's crop..$^{71}$

\section{[Table 5 here]}

Information about the ship, its master and crew, and the quality and value of its cargo, at least on the outward route to Africa, was of less significance in Bristol than route and timing, given that so many local underwriters were part-insurers of their own ships or those of their business partners and neighbors. To that extent, provincial underwriters may have had information advantages over their counterparts at Lloyd's when assessing risks, though it is still unclear whether this was reflected in differential rates.

Generally, slaves were included in the general rate for the ship and/or cargo. Some, though not all, policies specified "negroes at $£ 30$ per head", increasing to $£ 40$ in the war years of the 1790s. This standard price seems to have been set in some relation to the expected average sale price of a "prime adult male" in the West Indies. Cargoes loaded on the African coast, of course, comprised a mixture of slaves by gender, height, age, and ethnicity, factors that, together with the condition of the slaves upon arrival at market, and the state of supply, demand and planters' credit requirements, would determine the average price

\footnotetext{
70 Davis, Rise, pp. 277-82, 292-7; Behrendt, "Merchants”; Behrendt, "Ecology." 71 Radburn, "Keeping."
} 
achieved by a ship's cargo. None of this could be known with any certainty at the outset of a voyage. In fact, the per capita insured value of slave cargoes appears, in general, to have been somewhat below the prices achieved in the 1780s by factors in the West Indies.

Both in peace and war, slaving insurance rates tended to be at the higher end of the scale charged by marine underwriters on British foreign trades. Yet as tables 3 and 5 demonstrate, they were by no means the highest. Slaving voyages, therefore, from the point of view of underwriters, were not extraordinarily risky. The relatively high premiums applied to the large cargoes, however, did amount to a significant cost burden for owners. Richardson and Inikori, separately, have estimated the proportion of outlay costs accounted for by insurance premiums. The figure for 74 voyages out of Liverpool, 1757-84, was 8.6 per cent, and for 60 'African ventures' $1757-1806$ it was 9.8 per cent. Thus during the second half of the eighteenth century insurance premiums amounted to nearly 10 per cent of outward voyage costs. The ratio must have been even higher during wartime. ${ }^{72}$ As Richardson has pointed out, this must have had an important effect on slavers' profits margins, though account must be taken of the fact that merchants were often paying some of the premiums to themselves as underwriters. ${ }^{73}$ Whether insurance amounted to a higher cost burden than in other trades remains an open question, owing to the lack of evidence on premium payments as a proportion of outlay costs in the latter. As tables $3 \mathrm{~b}$ and $3 \mathrm{c}$ indicate, the higher premium rates on the middle passage inflated the cost of insurance for slave traders, at least in peacetime, while rates on the other two legs of the slaving voyage were more aligned with standard bilateral voyage rates in the direct trade. It may be the case that the larger crews on

72 Richardson, "Profits", appendix; Inikori, Africans, appendix 7.2.

73 Richardson, "Profits", p.74. 
slave voyages compounded the impact of insurance on total costs. ${ }^{74}$ However their impact is is uncertain, for even if slaving was more labor intensive, ship-owners tried to mitigate these costs by discharging "surplus" crew at the earliest possible opportunity. As Richardson has shown, crew per ton ratios were much higher on outward slave voyages from Bristol and Liverpool in the late eighteenth century than for the homeward leg to England. ${ }^{75}$ Manning rates of slave ships on their outward journey involved an element of risk management, reflecting the need for crew to oversee the slaves as well as navigate the ship and the fact that, due to exposure to tropical disease and other factors, slave ship crews experienced exceptionally high rates of mortality, with many failing to reach the Americas. Evidence from muster rolls, however, shows that, despite such losses it was still commonplace for masters to discharge some crew in the colonies, retaining a skeleton crew to sail the ship home. Economies could be achieved therefore in the monthly wage bill of slave ships, but the human nature of their cargo meant that labor costs, like middle passage insurance charges, weighed heavily on the financial balance sheet of slaving voyages.

\section{What did insurance cover and not cover?}

As we have seen, slaving voyages were insured on the standard Lloyd's policy form (or its Bristol and Liverpool counterparts), which listed the usual "perils of the sea". ${ }^{76}$ Ships and cargoes were covered from departure in England to arrival on the African coast, usually - not

74 Behrendt, "Human Capital". Our thanks to an anonymous referee for this suggestion. 75 Richardson, "Costs of Survival”, p.190. It should be noted, however, that recent research has questioned the consistency of tonnage measurements in the trade. Solar and Duquette, "Ship Crowding".

76 See note 19 above. 
always - with the destination left unspecified, and up to 24 hours after safely beginning trading there. In the majority of policies cover then resumed from Africa to the Americas, again usually with destination ports left unspecified, to give the captain the opportunity to sail between islands looking for the best market. Excluded was the underwriters' liability for any lack of seaworthiness of the vessel at time of departure ${ }^{77}$; losses while trading or transporting slaves in boats on the African coast and in rivers - though this was not always specified; worm damage to hulls due to delays in sailing from tropical rivers - some policies, though not all, required hulls to be copper sheathed as a condition of insurance; and the "natural deaths" of slaves. The latter was normally left unspecified in the policy contract. It is clear, however, from their everyday business accounts that underwriters and merchants commonly understood it to mean any slave deaths on board from illness, beatings or torture, suicide or fasting to death, and that they took it to be the equivalent of the standard exemption from liability for the ordinary spoilage, wastage, leakage or poor handling and storage of other perishable goods such as corn, fish, salt, fruit, flour and seed. These were commonly warranted "free from particular average", by which their particular value could not be claimed for unless it was included in any general claim for loss or damage to ship and cargo on which all insurers would pay in proportion to the sums they had individually written. We have found no actuarial calculation by underwriters of the "natural mortality" of slaves on slaving voyages. There was a lot of discussion in the business records between owners, captains and factors about mortality on individual ships, but this was only ever in relation to what was deemed to be a "paying voyage".

As noted above, underwriters were also commonly exempt from liability for any loss or damage to the ship and cargo caused by slave revolt up to ten, or sometimes five, per cent

77 This was confirmed by a court ruling of 1764, Wright and Fayle, History, p.148. 
of the net outlay value of the ship and cargo. Any losses above that level would be paid for under general average. On a $£ 6000$ policy, assuming this covered the full value of the outlay, at $£ 30$ per head a minimum of 20 slaves would have to die directly in a shipboard revolt before underwriters would begin to pay for losses. ${ }^{78}$

This was a hefty "excess" for owners to carry. ${ }^{79}$ The ten per cent insurrection exemption clause was intended to reduce the moral hazard of the wilful murder of slaves on board, to encourage owners and captains to take proper safety precautions in controlling and preserving the value of these and other perishable cargoes, and to remove the opportunity for small and vexatious claims for losses at sea due to negligence. Taken together, these exclusions, plus the other devices to mitigate moral hazard, such as "privilege" slaves for masters and chief officers and "head" money for surgeons (enhanced by the bonuses paid to them for low shipboard mortality rates under the 1788 Dolben Act), made the underwriting of

78 Cf. the $£ 6000$ policy on the Bristol slaver Daniel in 1792, TNA, C107/11, James Rogers Papers, Inset notes for the Swift, Henry Laroche, Africa to Grenada. 79 It has been estimated that one in 10 slaving voyages experienced a revolt of some kind, with an average of 25 slave deaths per revolt. But this average was heavily skewed by a small number of revolts with catastrophic mortality. The median number of deaths was less than half the mean, and 37 per cent of revolts resulted in five or fewer slave deaths. Behrendt, Eltis and Richardson, "Costs of Coercion", 461-4. In the later eighteenth century only the smallest British voyages, with total outlays of $£ 4000$ or less, at a $£ 30$ per head valuation and experiencing the median number of shipboard revolt deaths, would have reached the excess (in this case 13 deaths) above which underwriters were liable. The average outlay on Bristol voyages in 1790 was $£ 8,500$. Richardson, Bristol, pp. xvii-xviii. 
slave voyages a far less precarious business than it otherwise might have been ${ }^{80}$ This helps to explain the relatively moderate rates charged in comparison, for example with the East Indian trade, or with northern European routes during wartime.

\section{CONCLUSIONS}

The primary conclusion about insuring transatlantic slave voyages from the perspective of underwriters, brokers and merchants is that it was a generally unexceptional business. Premium rates were not astronomically high compared to other trades, especially during wartime. Premiums were not strictly actuarial in the sense that they did not reflect the real loss frequency of slave shipping on the different segments of the triangular trade, but the same was probably true for the insurance of all other types of cargo. Average slave ship losses and captures over the period 1760-1807 were not exceptionally high, especially in the middle passage. The proportion of British ships lost (gross of recaptures) was 7.7 per cent in 1793-1801, and 9.5 per cent in the worst years of the American war $1779-82 .{ }^{81}$ With a loss rate of 6.5 per cent between 1760 and 1810, a period covering war and peace, British slaving voyages were no more risky than general foreign trades during war years. In fact, as we have seen, more British slave ships were lost on the legs of the triangular route without slave cargoes than with.

80 The Dolben Act stipulated bonuses for masters and surgeons on vessels achieving mortality rates below three per cent. It has been argued, however, that this had little effect on overall slave mortality which was 5.7 per cent between 1791 and 1797. Klein and Engerman, "Slave Mortality".

81 Calculated from Wright and Fayle, History, pp.156-7, 451-5. 
The process of underwriting slaves differed little in practice from that of other maritime trades. Levels of self-insurance, though perhaps not under-insurance, may have been rather higher than in other trades, but the contracts were standard. Slaves were insured in policies alongside a wide range of other commodities traded across oceans, such as textiles, guns, hardware, beads, and a variety of raw materials. The extent to which cargoes and ships were monitored, and the exemptions from liability built into policies, point to the trade being relatively safe, and probably profitable, for insurers over time, not least because the latter concentrated on covering the standard perils of the seas, while the slave merchants themselves had to find ways of mitigating or managing most of the perils associated with their human cargoes.

The agency of slaves in taking decisions over their lives through suicide, jumping overboard, shipboard revolt, and fasting to death resulted in a marginally greater number of exemptions from liability being built into insurance contracts than in other maritime trades, but that was only a difference of degree not substance. Among those directly involved in the trade slaves were commonly regarded as animate and perishable goods, and no more than that. Even where the welfare of slaves - their diet, quality of provisions, medical treatment was critically remarked upon by traders, factors and masters in private business correspondence, it was only ever in the context of protecting the value of an asset, with a view to achieving a high average price at sale. ${ }^{82}$

82 A typical example is TNA, C107/13, James Rogers Papers, Wm Woodville jr. to James Rogers, Bannee [Bonny], 16 May 1791. 


\section{REFERENCES}

Anstey, Roger. The Atlantic Slave Trade and British Abolition 1760-1810. Aldershot: Gregg Revivals, 1992.

Armstrong, Tim. "Slavery, Insurance and Sacrifice in the Black Atlantic." In Sea Changes:

Historicizing the Ocean, edited by B. Klein and G. Mackenthun, 167-85. New York:

Routledge, 2004.

Behrendt, Stephen D. “Merchants, Transaction Cycles, and Profits: Merchant Decision Making in the British Slave Trade.” William and Mary Quarterly 58 (2001): 171-205.

Behrendt, Stephen D. "Human Capital in the British Slave Trade.” In Liverpool and Transatlantic Slavery, edited by David Richardson, Suzanne Schwarz and Anthony Tibbles, 66-97. Liverpool: Liverpool University Press, 2007.

Behrendt, Stephen D. "Ecology, Seasonality and the Transatlantic Slave Trade.” In Soundings in Atlantic History: Latent Structures and Intellectual Currents, 1500-1830, edited by Bernard Bailyn and Patricia L. Denault, 44-85. Cambridge, MA: Harvard University Press, 2009.

Behrendt, Stephen D., Eltis , David and Richardson, David. "The Costs of Coercion: African Agency in the Pre-Modern Atlantic World”. Economic History Review 54 (2001): 454-76.

Carlos, Ann M. "Bonding and the Agency Problem: Evidence from the Royal African Company, 1672-1691”. Explorations in Economic History 31 (1994): 313-35.

Clark, Geoffrey. Betting on Lives: The Culture of Life Insurance in England, 1695-1775. Manchester: Manchester University Press, 1999. 
Clark, Geoffrey. “The Slave's Appeal: Insurance and the Rise of Commercial Property.” In The Appeal of Insurance, edited by Geoffrey Clark, Gregory Anderson, Christian Thomann and J-Matthias Graf von der Schulenburg, 52-74. Toronto: University of Toronto Press, 2010. Cockerell, H. A. L. and Green, Edwin. The British Insurance Business, 1547-1970: A Guide to its History and Records. Sheffield: Sheffield Academic Press, 1994.

Davis, David Brion, "Foreword”. In Atlas of the Transatlantic Slave Trade., by David Eltis and David Richardson. New Haven: Yale University Press, 2010.

Curtin, Philip D. The Atlantic Slave Trade: A Census. Madison: University of Wisconsin Press, 1969.

Dalton, John T. and Leung, Tin Cheuk. "Dispersion and Distortions in the Trans-Atlantic Slave Trade.” Journal of International Economics 96 (2015): 412-25.

Davis, Ralph. The Rise of the English Shipping Industry in the $17^{\text {th }}$ and $18^{\text {th }}$ Centuries. Newton Abbot: David \& Charles, 1962.

Del Treppo, Mario. “Assicurazioni e Commercio Internazionale a Barcellona nel 14281429.” Rivista Storica Italiana 69 (1957): 508-41.

Devine, T.M. The Tobacco Lords: A Study of the Tobacco Merchants of Glasgow and their Trading Activities 1740-1790. Edinburgh: Edinburgh University Press, 1975.

Draper, N. "The City of London and Slavery: Evidence from the First Dock Companies, 1795-1800.” Economic History Review 61 (2008): 432-66.

Eltis, David and Engerman, Stanley. "The Importance of Slavery and the Slave Trade to Industrializing Britain.” Journal of Economic History 60 (2000): 123-144. 
Eltis, David, Lewis, Frank D. and Richardson, David. "Slave Prices, the African Slave Trade, and Productivity in the Caribbean, 1674-1807." Economic History Review 58 (2005): 673700.

Émerigon, Balthazard-Marie. Traité des Assurances et Des Contrats à la Grosse. 2 vols. Marseille: Jean Mossy, 1783.

Geggus, David. “The French Slave Trade: An Overview.” The William and Mary Quarterly 58 (2001): 119-38.

Haggerty, Sheryllynne. "Risk and Risk Management in the Liverpool Slave Trade." Business History 51 (2009): 817-34.

Inikori, Joseph E. "Market Structure and the Profits of the British African Trade in the Late Eighteenth Century.” Journal of Economic History 41 (1981): 745-76.

Inikori, Joseph E. Africans and the Industrial Revolution in England: A Study in International Trade and Economic Development. Cambridge: Cambridge University Press, 2002. John, A. H. "The London Assurance Company and the Marine Insurance Market of the Eighteenth Century.” Economica 25 (1958): 126-41.

Kingston, Christopher. "Marine Insurance in Britain and America, 1720-1844: A Comparative Institutional Analysis.” Journal of Economic History 67 (2007): 379-409.

Klein, Herbert S. The Atlantic Slave Trade. Cambridge: Cambridge University Press, 1999. Klein, Herbert S. and Engerman, Stanley L. "Slave Mortality on British Ships, 1791-1797." In Liverpool, the African Slave Trade, and Abolition: Essays to Illustrate Current Knowledge and Research, edited by Roger Anstey and P. E. H. Hair, 113-25. Liverpool: Historic Society of Lancashire and Cheshire, Occasional Series, vol. 2 (1989). 
Leonard, Adrian. "Contingent Commitment: The Development of English Marine Insurance in the Context of New Institutional Economics, 1577-1720." In Questioning Credible Commitment: New Perspectives on the Rise of Financial Capitalism, edited by D'Maris Coffman, Adrian Leonard and Larry Neal, 48-75. Cambridge: Cambridge University Press, 2013.

Lobban, Michael. "Slavery, Insurance and the Law." Journal of Legal History 28 (2007): $319-28$.

Magens, Nicholas. An Essay on Insurances. 2 vols. London: J. Haberkorn ,1755.

Marryat, Joseph. Observations upon the Report of the Committee of Marine Insurance.

London: W. Hughes, 1810. Reprinted in History of Insurance: Volume 8 - Marine, edited by

David Jenkins and Takau Yoneyama, 209-99. London: Pickering \& Chatto, 2000.

Miller, Joseph. Way of Death: Merchant Capitalism and the Angolan Slave Trade 1730-1830.

Madison: University of Wisconsin Press, 1988.

Mitchell, Brian R. British Historical Statistics. Cambridge: Cambridge University Press, 1988.

Morgan, Kenneth. “Liverpool's Dominance in the British Slave Trade, 1740-1807.” In Liverpool and Transatlantic Slavery, edited by David Richardson, Suzanne Schwarz and Anthony Tibbles, 14-42. Liverpool: Liverpool University Press, 2007.

Oldham, James. "Insurance Litigation Involving the Zong and Other British Slave Ships, 1780-1807." Journal of Legal History 28 (2007): 299-318.

Park, Sir James Allan. A System of the Law of Marine Insurances. $5^{\text {th }}$ edn. London: J. Butterworth, 1802.

Pearson, Robin. "Collective Diversification: Manchester Cotton Merchants and the Insurance Business in the Early Nineteenth Century.” Business History Review 65 (1991): 379-414. 
Pearson, Robin and Richardson, David. "Business Networking in the Industrial Revolution." Economic History Review 54 (2001): 657-79.

Pearson, Robin. Insuring the Industrial Revolution: Fire Insurance in Great Britain, 17001850. Aldershot: Ashgate, 2004.

Postma, Johannes Menne. The Dutch in the Atlantic Slave Trade. Cambridge: Cambridge University Press, 1990.

Radburn, Nicholas. “Keeping 'the Wheel in Motion': Trans-Atlantic Credit Terms, Slave Prices, and the Geography of Slavery in the British Americas, 1755-1807.” Journal of Economic History 75 (2015): 660-689.

Raynes, Harold E. A History of British Insurance. London: Sir Isaac Pitman, 1948.

Richardson, David. "The Costs of Survival: The Transport of Slaves in the Middle Passage and the Profitability of the $18^{\text {th }}$-Century British Slave Trade." Explorations in Economic History 24 (1987): 178-196.

Richardson, David. "Profits in the Liverpool Slave Trade: the Accounts of William Davenport, 1757-1784." In Liverpool, the African Slave Trade, and Abolition: Essays to Illustrate Current Knowledge and Research, edited by Roger Anstey and P. E. H. Hair, 6090. Liverpool: Historic Society of Lancashire and Cheshire, Occasional Series, vol. 2 (1989). Richardson, David (ed.). Bristol, Africa and the Eighteenth-Century Slave Trade to America, vol.4. Bristol: Bristol Record Society Publications, 47, 1996.

Roover, F. Edler de. "Early Examples of Marine Insurance.” Journal of Economic History 5 (1945): 172-200.

Rupprecht, Anita. “Excessive Memories: Slavery, Insurance and Resistance.” History Workshop Journal 64 (2007): 6-28. 
Rupprecht, Anita. “ 'A Very Uncommon Case': Representations of the Zong and the British Campaign to Abolish the Slave Trade.” Journal of Legal History 28 (2007): 329-46.

Rupprecht, Anita. ““A Limited Sort of Property’: History, Memory and the Slave Ship Zong." Slavery and Abolition 29 (2008): 265-77.

Solar, Peter M. and Duquette, Nicholas J. "Ship Crowding and Slave Mortality: Missing Observations or Incorrect Measurement?” Journal of Economic History 77 (2017): 11771202.

Stein, Robert L. The French Slave Trade in the Eighteenth Century: An Old Regime Business. Madison: University of Wisconsin Press, 1979.

Supple, Barry. The Royal Exchange Assurance: A History of British Insurance 1720-1970. Cambridge: Cambridge University Press, 1970.

Swaminathan, Srividhya. "Reporting Atrocities: A Comparison of the Zong and the Trial of Captain John Kimber.” Slavery and Abolition 31 (2010): 483-99.

Valin, René-Josué. Nouveau commentaire sur l'ordonnance de la marine, du mois d'août 1681. 2 vols. La Rochelle: J. Legier, 1776.

Viles, Perry . "The Slaving Interest in the Atlantic Ports 1763-1792.” French Historical Studies 7 (1972): 529:43.

Walford, Cornelius, Insurance Cyclopedia, vol.3. London: Charles and Edward Layton, 1874.

Walvin, James. The Zong: A Massacre, the Law, and the End of Slavery. New Haven CT: Yale University Press, 2011.

Webster, Jane. "The Zong in the Context of the Eighteenth-Century Slave Trade." Journal of Legal History 28 (2007): 285-98. 
Weskett, John . A Complete Digest of the Theory, Laws, and Practice of Insurance. London: Frys, Couchman and Collier, 1781.

Wright, Charles and Fayle, C. Ernest. A History of Lloyd's: from the Founding of Lloyd's Coffee House to the Present Day. London: Macmillan, 1928.

Zahadieh, Nuala. “Overseas Trade and Empire.” In The Cambridge Economic History of Modern Britain. Volume 1 1700-1870, edited by Roderick Floud, Jane Humphries and Paul Johnson, 392-420. Cambridge: Cambridge University Press, 2014. 
Table 1: Estimating British marine insurance

1.1. Inikori's estimates

\begin{tabular}{|l|r|r|r|c|}
\hline & \multicolumn{1}{|c|}{ A } & \multicolumn{1}{c|}{ B } & \multicolumn{1}{c|}{ D } & D \\
\hline & $\begin{array}{r}\text { Average annual } \\
\text { premiums (£), } \\
\text { London } \\
\text { Assurance }\end{array}$ & $\begin{array}{r}\text { Average annual } \\
\text { premiums (£m), } \\
\text { British marine } \\
\text { insurance }\end{array}$ & $\begin{array}{r}\text { Average annual } \\
\text { premiums (£m), } \\
\text { Slave and West } \\
\text { Indian trades }\end{array}$ & C as \% of B \\
\hline $1720-50$ & 35,000 & 1.80 & & \\
\hline $1750-92$ & 38,000 & 2.00 & & 63.0 \\
\hline $1793-1807$ & 76,000 & 4.00 & & \\
\hline 1809 & 228,000 & 10.95 & & \\
\hline
\end{tabular}

Sources and Notes: Column A: Inikori, Africans, p.342n87. Inikori's figures derive from the graph in John, "London Assurance", p.130. Inikori states that the average for 1793-1807 was "roughly twice" that for 1750-92, and the figure for 1809 was "roughly three times" the average of 1793-1807; Column B: The figure for 1809 is given in Angerstein's evidence to the Select Committee on Marine Insurance, BPP 1810, IV, 314-15. As explained in Inikori, Africans, p.342n88, the other figures are the product of the ratios between the average premiums of London Assurance for the different periods. Thus, as its premiums in 1793-1807 were one third (not three times as stated in Inikori, Africans, p.342n88) of those in 1809, the annual average premiums for UK marine insurance 1793-1807 are "put at approximately $£ 4$ m”. London Assurance's average premiums in 1750-92 were half those in 1793-1807, so the UK average for $1750-92$ is $£ 2 \mathrm{~m}$. Inikori states that "the figure for $1720-50$ is a marginal adjustment arising from the closeness of the company's premium earnings in 1750-92 and 1720-50"; Column C: Inikori, Africans, p.356. Inikori estimates premiums of $£ 2.52 \mathrm{~m}$ from the slave and West Indian trades by applying average premium rates to his estimates of the value of these trades (ships, outfit, goods, slaves). $£ 2.52 \mathrm{~m}$ relates to the period 1791-1800, 
but is applied by Inikori to his estimate of total marine insurance for 1793-1807 to produce the percentage in column D.

1.2. New estimates

\begin{tabular}{|c|c|c|c|c|c|c|c|}
\hline & & & Average a & nual pren & iums $£ m$ & & \\
\hline & $\mathrm{A}$ & B & $\mathrm{C}$ & $\mathrm{D}$ & $E$ & & \\
\hline & $\begin{array}{l}\text { Corporations' } \\
\text { combined } \\
\text { premiums - } \\
\text { average } £ \text { p.a. }\end{array}$ & $\begin{array}{l}\text { Corporations' } \\
\text { combined } \\
\text { share } \%\end{array}$ & $\begin{array}{l}\text { Total UK } \\
\text { marine } \\
\text { insurance }\end{array}$ & $\begin{array}{l}\text { Slave } \\
\text { trade } \\
\text { only }\end{array}$ & $\begin{array}{l}\text { Slave \& } \\
\text { WI } \\
\text { trades }\end{array}$ & $\begin{array}{l}\mathrm{D} \text { as } \% \\
\text { of } \mathrm{C}\end{array}$ & $\begin{array}{l}\mathrm{E} \text { as \% } \\
\text { of } \mathrm{C}\end{array}$ \\
\hline $\begin{array}{l}1760 / 1- \\
1769 / 70\end{array}$ & 69,649 & 5.0 & 1.39 & 0.11 & & 7.9 & \\
\hline $\begin{array}{l}1770 / 1- \\
1779-80\end{array}$ & 73,298 & 4.5 & 1.63 & 0.08 & & 4.9 & \\
\hline $\begin{array}{l}1780 / 1- \\
1789 / 90 \\
\end{array}$ & 135,600 & 5.0 & 2.71 & 0.11 & & 4.1 & \\
\hline $\begin{array}{l}1790 / 1- \\
1799 / 00\end{array}$ & 280,451 & 4.5 & 6.23 & 0.41 & 2.52 & 6.6 & 40.5 \\
\hline $\begin{array}{l}1800 / 1- \\
1809 / 10\end{array}$ & 263,125 & 3.89 & 6.76 & 0.53 & & 7.8 & \\
\hline 1809 & & 3.79 & 10.95 & & & & \\
\hline
\end{tabular}

Sources and Notes: Column A: Supple, Royal Exchange, p.61n2 and table 3.1. We have raised London Assurance's net premiums (net of returns) by 25 per cent to estimate gross premiums, following the note in Supple's table 3.1, and added them to those of Royal Exchange Assurance; Column B: The percentage figure for 1809 is the two corporations' combined insurance $(£ 6,155,755)$ as a share of total UK marine insurance $(£ 162,538,900)$, as estimated by the Select Committee, BPP 1810, IV, 250, from company returns and from stamp duty collected on marine insurance policies that year. The figure for $1800 / 1-1809 / 10$ is the corporations' combined share of stamp duty paid on policies $1800-09$. This probably overstates the corporations' share (and therefore understates total UK marine insurance) because of widespread evasion of duty by private underwriters before 1808. See Marryat, Observations, p.289. Percentages for 1760-1800 are estimates based on the following 
assumptions: (i) that the corporations’ share of total duty paid in $1800(£ 5,355$ out of $£ 113,442$, or 4.7 per cent) approximates the corporations' market share in 1790-99, once adjusted downwards (to 4.5 per cent) to allow for some evasion of the stamp duty by private underwriters; (ii) that the two corporations kept pace with Lloyd's through to 1790; (iii) that their market share was lower during wartime years due to more conservative underwriting, their refusal to insure cross-risks, their higher rates, stricter policy conditions, and the accelerated growth of Lloyds after 1793. See Kingston, "Marine Insurance”. Column C: The figure for 1809 is Angerstein's estimate. All other UK marine insurance premiums are estimated by multiplying up the corporations' combined premiums by the market shares given in column B. Columns C and D: the premium estimates given by Inikori, Africans, tables 7.3 and 7.6. 
Table 2. Total slave arrivals in the Caribbean (5 year totals)

\begin{tabular}{|l|l|}
\hline $1756-60$ (war) & 101,449 \\
\hline $1761-5$ (war and peace) & 164,311 \\
\hline $1766-70$ (peace) & 245,938 \\
\hline $1771-5$ (peace) & 264,900 \\
\hline $1776-80$ (war) & 140,535 \\
\hline $1781-5$ (war and peace) & 189,971 \\
\hline $1786-90$ (peace) & 307,060 \\
\hline
\end{tabular}

Source: Eltis, Lewis, and Richardson, "Slave Prices", table 4, p.691. 
Table 3: Insurance rates for British slaving voyages (£\%)

(A) Inikori's rates

\begin{tabular}{|l|c|c|c|}
\hline & 1 & 2 & 3 \\
\hline & England to Africa & Africa to Americas & Americas to England \\
\hline $1701-13$ & 4.0 & 8.0 & 10.0 \\
\hline $1714-38$ & 2.0 & 4.5 & 4.5 \\
\hline $1739-48$ & 4.0 & 8.0 & 10.0 \\
\hline $1749-55$ & 2.0 & 4.5 & 4.5 \\
\hline $1756-62$ & 6.0 & 10.0 & 10.0 \\
\hline $1763-75$ & 2.0 & 4.5 & 4.5 \\
\hline $1776-82$ & 5.0 & 10.0 & 10.0 \\
\hline $1783-92$ & 2.0 & 4.5 & 4.5 \\
\hline $1793-1807$ & 8.0 & 12.0 & 14.0 \\
\hline
\end{tabular}

(B) Clibborn's rates, 1769-75 $(\mathrm{N}=330)$

\begin{tabular}{|r|l|r|r|}
\hline & & No of policies & Average rate \\
\hline 1 & England to Africa & 16 & 2.3 \\
\hline 2 & Africa to America & 46 & 4.8 \\
\hline 3 & America to England & 29 & 4.3 \\
\hline 4 & England to Africa \& America & 227 & 6.6 \\
\hline 5 & England to Africa \& return & 1 & 10.5 \\
\hline 6 & America to Africa \& return & 1 & 8.4 \\
\hline 7 & Time policies (no route) & 10 & 6.2 \\
\hline 8 & All policies & 330 & 5.9 \\
\hline
\end{tabular}

(C) Rogers' rates, 1784-93 $(\mathrm{N}=69)$

\begin{tabular}{|l|l|r|r|r|r|}
\hline & & \multicolumn{2}{|c|}{$1784-92$} & \multicolumn{2}{|c|}{1793} \\
\hline & $\begin{array}{r}\text { No of } \\
\text { policies }\end{array}$ & $\begin{array}{r}\text { Average } \\
\text { rate }\end{array}$ & $\begin{array}{r}\text { No of } \\
\text { policies }\end{array}$ & $\begin{array}{r}\text { Average } \\
\text { rate }\end{array}$ \\
\hline 1 & England to Africa & 18 & 2.4 & & \\
\hline 2 & Africa to America & 12 & 4.0 & 7 & 9.3 \\
\hline 3 & America to England & 6 & 3.9 & 6 & 13.5 \\
\hline 4 & England to Africa \& America & 15 & 6.1 & & \\
\hline 5 & Africa to England & 3 & 3.3 & & \\
\hline 6 & England to America & 2 & 2.0 & & \\
\hline 7 & All policies & 56 & 4.5 & 13 & 10.8 \\
\hline
\end{tabular}

Notes: (1) All average rates are expressed as $£$ premiums paid per $£ 100$ insured, the standard metric used by contemporary insurers; (2) Inikori states his "rates represent a rather conservative average view of the differing rates in the sources cited" (p.350). He does not 
state the number of policies on which his rates were calculated. (3) Rogers was declared bankrupt in 1793 and apparently insured no outward slaving voyages departing from England that year.

Sources: (A): Rates as given in Inikori, Africans, table 7.2, p.350; (B): Calculated from amounts insured and premiums paid as given in TNA, C107/11, Underwriting books of Abraham Clibborn, 1768/9-1775; (C): Calculated from amounts insured and premiums paid as given in TNA, C107/1-15, James Rogers Papers. 
Table 4: Shipping losses in the transatlantic slave trade

\begin{tabular}{|l|r|r|r|r|}
\hline & \multicolumn{2}{|c|}{ All voyages } & \multicolumn{2}{c|}{ British voyages } \\
& \multicolumn{2}{|c|}{$1519-1867$} & \multicolumn{2}{c|}{$1760-1810$} \\
\hline & Number & $\%$ loss & Number & $\%$ loss \\
\hline 1. Total voyages & 35,942 & & 6,146 & \\
\hline $\begin{array}{l}\text { 2. Voyages with unknown } \\
\text { outcome }\end{array}$ & 3,749 & & 4,150 & \\
\hline 3. Completed as intended & 16,805 & & 397 & 6.5 \\
\hline $\begin{array}{l}\text { 4. Total ships wrecked/destroyed } \\
\text { 5. Ships wrecked/destroyed } \\
\text { before slaving }\end{array}$ & 1,013 & 3.1 & 64 & \\
\hline $\begin{array}{l}\text { 6. Ships wrecked/destroyed while } \\
\text { slaving }\end{array}$ & 249 & & 184 & \\
\hline $\begin{array}{l}\text { 7. Ships wrecked/destroyed after } \\
\text { slaves disembarked }\end{array}$ & 453 & & & \\
\hline $\begin{array}{l}\text { 8. Ships wrecked/destroyed - } \\
\text { unspecified }\end{array}$ & 60 & & & \\
\hline
\end{tabular}

Source: Based on www.slavevoyages.org, accessed 1 May 2017. Search database/basic variables/all voyages and nation/flag/Great Britain, for line 1; basic variables/voyage outcome/outcome of voyage for owner, for line 2; general variables/voyage outcome/particular outcome of voyage/menu options 'shipwreck', for all other lines.

Note: percentage losses are computed by dividing totals in row 4 by the sum of voyages with known outcomes (i.e. row 1 less row 2). 
Table 5: Non-slaving marine insurance rates: premium rates charged by London Assurance on voyages to and from London, 1768-70 (£\%)

\begin{tabular}{|l|r|r|r|r|}
\hline & \multicolumn{2}{|c|}{ Summer } & \multicolumn{2}{c|}{ Winter } \\
\hline & \multicolumn{1}{|c|}{ Out } & \multicolumn{1}{c|}{ Home } & \multicolumn{1}{c|}{ Out } & \multicolumn{1}{c|}{ Home } \\
\hline Newcastle on Tyne & & 0.75 & & 1.00 \\
\hline Dublin & & 1.05 & 1.25 & 1.50 \\
\hline Hamburg & 1.00 & 1.00 & & 2.00 \\
\hline Bilbao & 1.25 & 1.25 & 1.50 & 1.25 \\
\hline Cadiz & 1.05 & 1.05 & 1.25 & 1.25 \\
\hline Smyrna & 1.75 & 1.50 & 2.00 & 2.00 \\
\hline North America & 2.10 & 2.10 & 2.10 & 2.10 \\
\hline Jamaica & 2.50 & 4.20 & 2.50 & 4.20 \\
\hline East Indies out and home & \multicolumn{2}{|l|}{$15.75^{*}$} & & \\
\hline
\end{tabular}

Sources and notes: John, "London Assurance", table 2. * John notes that $£ 8$ of the East Indies premium was to be returned "if no hostilities in European waters". All rates are shown as $£$ premiums paid per $£ 100$ insured (or $£ \%$ ). 